\title{
Desulfoconvexum algidum gen. nov., sp. nov., a psychrophilic sulfate-reducing bacterium isolated from a permanently cold marine sediment
}

Correspondence Martin Könneke koenneke@uni-bremen.de

\author{
Martin Könneke, ${ }^{1} \dagger$ Jan Kuever, ${ }^{2}$ Alexander Galushko ${ }^{1} \ddagger$ \\ and Bo Barker Jørgensen ${ }^{1} \S$
}

\author{
${ }^{1}$ Max-Planck Institute for Marine Microbiology, Bremen, Germany \\ ${ }^{2}$ Bremen Institute for Materials Testing, Bremen, Germany
}

\begin{abstract}
A sulfate-reducing bacterium, designated $\mathrm{JHA} 1^{\top}$, was isolated from a permanently cold marine sediment sampled in an Artic fjord on the north-west coast of Svalbard. The isolate was originally enriched at $4{ }^{\circ} \mathrm{C}$ in a highly diluted liquid culture amended with hydrogen and sulfate. Strain $\mathrm{JHA} 1^{\top}$ was a psychrophile, growing fastest between 14 and $16{ }^{\circ} \mathrm{C}$ and not growing above $20{ }^{\circ} \mathrm{C}$. Fastest growth was found at neutral $\mathrm{pH}(\mathrm{pH} 7.2-7.4)$ and at marine concentrations of $\mathrm{NaCl}(20-$ $30 \mathrm{~g} \mathrm{I}^{-1}$ ). Phylogenetic analysis of $16 \mathrm{~S}$ rRNA gene sequences revealed that strain $\mathrm{JHA} 1^{\top}$ was a member of the family Desulfobacteraceae in the Deltaproteobacteria. The isolate shared $99 \%$ 16S rRNA gene sequence similarity with an environmental sequence obtained from permanently cold Antarctic sediment. The closest recognized relatives were Desulfobacula phenolica DSM $3384^{\top}$ and Desulfobacula toluolica DSM $7467^{\top}$ (both $<95 \%$ sequence similarity). In contrast to its closest phylogenetic relatives, strain $\mathrm{JHA} 1^{\top}$ grew chemolithoautotrophically with hydrogen as an electron donor. $\mathrm{CO}$ dehydrogenase activity indicated the operation of the reductive acetyl-CoA pathway for inorganic carbon assimilation. Beside differences in physiology and morphology, strain $\mathrm{JHA} 1^{\top}$ could be distinguished chemotaxonomically from the genus Desulfobacula by the absence of the cellular fatty acid $C_{16: 0} 10$-methyl. Phylogenetic differentiation from other genera was further supported by DsrAB and AprBA sequence analysis. Based on the described phylogenetic and phenotypic differences between strain $\mathrm{JHA} 1^{\top}$ and its closest relatives, the establishment of a novel genus and a novel species, Desulfoconvexum algidum gen. nov., sp. nov. is proposed. The type strain is $\mathrm{JHA} 1^{\top}\left(=\mathrm{DSM} 21856^{\top}=\mathrm{JCM} 16085^{\top}\right)$.
\end{abstract}

Anaerobic degradation of organic matter in marine sediments generally proceeds via several steps of catabolic processes which are catalysed by a variety of microorganisms. Since sulfate occurs at a high concentration in ocean water, the dissimilatory reduction of sulfate represents the major terminal remineralization process in

†Present address: Organic Geochemistry Group, Department of Geosciences and MARUM Center for Marine Environmental Sciences, University of Bremen, Germany

‡Present address: Department of Microbial Ecology, University of Vienna, Austria

§Present address: Center for Geomicrobiology, Department of Bioscience, Aarhus University, Denmark

Abbreviation: SRB, Sulfate-reducing bacteria.

The GenBank/EMBL/DDBJ accession numbers for the 16S rRNA gene, dsrAB and aprBA sequences of strain $J H A 1^{\top}$ are EF442984, J0901403 and EF442915, respectively.

Two supplementary figures are available with the online version of this paper. anoxic marine sediments (Jørgensen, 1982). The major electron donors for sulfate reduction are end products of fermentation, such as short-chain organic acids and hydrogen (Rabus et al., 2000). The concentrations of these compounds in marine sediments are generally low, indicating the close coupling of fermentation and the terminal oxidation step (Finke \& Jørgensen, 2008).

Most of the ocean's seafloor, including the deep ocean and polar coastal areas, exhibits permanently cold conditions. Yet, only a limited number of psychrophilic or psychrotolerant sulfate-reducing bacteria (SRB) have been isolated so far. However, rates of in situ sulfate reduction in permanently cold sediments at the coast of the Svalbard archipelago have been determined to be as high as those of temperate marine sediments, pointing to the occurrence of cold-adapted SRB (Sagemann et al., 1998). From the same location, novel psychrophilic SRB were selectively isolated at low temperatures with acetate, lactate or propionate as the electron donors (Knoblauch \& Jørgensen, 1999, Knoblauch et al., 1999) and most of the described isolates 
Table 1. Selected characteristics for differentiation of strain $\mathrm{JHA} 1^{\top}$ from its closest relatives

Strains: 1, Desulfoconvexum algidum gen. nov., sp. nov. JHA1 ${ }^{\mathrm{T}}$; 2, Desulfobacula toluolica (DSM $7467^{\mathrm{T}}$ ) (data from Rabus et al., 1993); 3, Desulfobacula phenolica (DSM 3384 ${ }^{\mathrm{T}}$ ) (Bak \& Widdel, 1986); 4, Desulfospira joergensenii (Finster et al., 1997). All strains used butyrate (5 mM) and fumarate (10 mM) as electron donors, and sulfate $(28 \mathrm{mM})$ and thiosulfate $(10 \mathrm{mM})$ as electron acceptors. SRWG, Sulfate reduction without growth; +, positive; - , negative; ND, no data available.

\begin{tabular}{|c|c|c|c|c|}
\hline Characteristic & 1 & 2 & 3 & 4 \\
\hline Cell morphology & Curved, vibrioid & Oval-coccoid & Oval to curved & Curved, vibrioid \\
\hline Cell width $(\mu \mathrm{m})$ & 1.5 & $1.2-1.4$ & $1-1.5$ & $0.7-0.8$ \\
\hline Cell length $(\mu \mathrm{m})$ & $2.0-3.5$ & $1.2-2.0$ & $2-3$ & $1-2$ \\
\hline Motility & + & + & + & - \\
\hline $\mathrm{G}+\mathrm{C}$ content $(\mathrm{mol} \%)$ & 46 & 42 & 41 & 49 \\
\hline \multicolumn{5}{|c|}{ Electron donors for sulfate reduction $(\mathrm{mM})$} \\
\hline Hydrogen & + & - & - & + \\
\hline Formate $(20)$ & + & - & + & + \\
\hline Acetate $(20)$ & - & - & + & - \\
\hline Propionate (15) & - & - & - & \\
\hline Valerate (5) & + & - & ND & ND \\
\hline Caproate (5) & + & - & - & ND \\
\hline Caprate (2) & + & ND & ND & ND \\
\hline Lactate (10) & + & - & - & + \\
\hline Malate (10) & + & + & + & - \\
\hline Succinate (10) & - & + & + & + \\
\hline Pyruvate (10) & - & + & + & + \\
\hline Ethanol (10) & + & + & + & - \\
\hline n-Propanol (10) & + & + & + & - \\
\hline n-Butanol (10) & + & + & + & - \\
\hline Methanol (10) & + & - & ND & SRWG \\
\hline Glycerol (10) & + & $\mathrm{ND}$ & $\mathrm{ND}$ & + \\
\hline Glycine (10) & + & $\mathrm{ND}$ & $\mathrm{ND}$ & SRWG \\
\hline Alanine (10) & + & $\mathrm{ND}$ & $\mathrm{ND}$ & SRWG \\
\hline Serine (10) & + & $\mathrm{ND}$ & ND & ND \\
\hline Betaine (10) & + & $\mathrm{ND}$ & $\mathrm{ND}$ & + \\
\hline Choline chloride (10) & + & ND & ND & + \\
\hline Proline (10) & + & ND & ND & + \\
\hline Sorbitol (10) & + & ND & ND & - \\
\hline Mannitol (5) & + & ND & ND & - \\
\hline Benzoate (3) & + & + & + & SRWG \\
\hline \multicolumn{5}{|l|}{ Electron acceptors (mM) } \\
\hline Sulfite (5) & - & ND & - & + \\
\hline Sulfur & + & ND & - & + \\
\hline Nitrate & - & $\mathrm{ND}$ & - & - \\
\hline \multicolumn{5}{|l|}{ Fermentable substrates $(\mathrm{mM})$} \\
\hline Pyruvate & - & $\mathrm{ND}$ & $\mathrm{ND}$ & - \\
\hline Malate & + & $\mathrm{ND}$ & $\mathrm{ND}$ & - \\
\hline Lactate & - & $\mathrm{ND}$ & ND & - \\
\hline Fumarate & + & $\mathrm{ND}$ & ND & - \\
\hline Autotrophy & + & - & - & + \\
\hline \multicolumn{5}{|l|}{ Conditions for growth } \\
\hline Range $\left({ }^{\circ} \mathrm{C}\right)$ & $0-20$ & $\mathrm{ND}$ & ND & $8-30$ \\
\hline Optimum $\left({ }^{\circ} \mathrm{C}\right)$ & $14-16$ & 28 & 28 & $26-30$ \\
\hline Optimum pH & $7.2-7.4$ & $7.0-7.1$ & ND & 7.4 \\
\hline Optimum $\mathrm{NaCl}\left(\mathrm{g} \mathrm{l}^{-1}\right)$ & $20-30$ & 20 & 20 & $12-20$ \\
\hline
\end{tabular}

belonged to the order Desulfobacterales. Further studies using molecular methods verified the presence of active and abundant SRB in several coastal sediments sampled from different fjords of the Svalbard archipelago (Sahm et al.,
1999; Ravenschlag et al., 1999, 2000, 2001). In order to culture and identify the potentially most abundant and active lithotrophic SRB from these fjords, liquid-dilution cultures were incubated at $4{ }^{\circ} \mathrm{C}$ with hydrogen or formate as the 
electron donor in combination with sulfate as the sole electron acceptor (Könneke, 2001). From dilution series with formate, seven isolates were obtained that were identified by 16S rRNA gene sequence analysis as Desulfotalea psychrophila or Desulfotalea arctica. Three lithotrophic SRB were isolated in pure culture with hydrogen as the sole electron donor. According to their 16S rRNA genes, two strains were affiliated with the Desulfobulbaceae within the Deltaproteobacteria, sharing highest identity with the psychrophilic SRB strain LSv53 (99.9\%) and an environmental 16S rRNA gene sequence (Sva0999; 97.2\%). The third pure culture, strain $\mathrm{JHAl}^{\mathrm{T}}$, was isolated from Smeerenburgfjorden and was found to be a member of the Desulfobacteraceae. Strain $\mathrm{JHAl}^{\mathrm{T}}$ was subjected to a phylogenetic, physiological and chemotaxonomic characterization and comparison with its closest described relatives, Desulfobacula phenolica DSM $3384^{\mathrm{T}}$, Desulfobacula toluolica DSM $7467^{\mathrm{T}}$ (both $<95 \% 16 \mathrm{~S}$ rRNA gene sequence similarity) and Desulfospira joergensenii DSM $10085^{\mathrm{T}}(<93 \%)$.

Strain $\mathrm{JHAl}^{\mathrm{T}}$ was isolated from sediment at a depth of $5 \mathrm{~cm}$ from a fjord on the north-west coast of Svalbard (Smeerenburgfjorden; $79^{\circ} 42^{\prime} 815^{\prime \prime} \mathrm{N} 11^{\circ} 05^{\prime} 189^{\prime \prime} \mathrm{E}$ ). The bottom water temperature during sampling (July 1998) was $0{ }^{\circ} \mathrm{C}$. Initial enrichment was performed in a 10,000 times dilution in defined carbonate-buffered saltwater medium (Widdel \& Bak, 1992) with hydrogen (headspace $\left.\mathrm{H}_{2} / \mathrm{CO}_{2} 90: 10\right)$ as the sole electron donor. Acetate $(1 \mathrm{mM})$ was provided as an alternative carbon source to bicarbonate/ $\mathrm{CO}_{2}$. Significant sulfide production was observed after an incubation period of 18 months at $4{ }^{\circ} \mathrm{C}$. Strain JHA1 ${ }^{\mathrm{T}}$ was isolated by the deep agar dilution technique (Widdel \& Bak, 1992) in three subsequent series in autotrophic medium with hydrogen. Purity was checked by microscopic observation and finally by transferring the strain into anoxic media containing yeast extract, peptone or glucose. Growth in these complex media was not observed. Further cultivation, growth experiments and strain maintenance were carried out with an inoculum volume of $5 \%$ $(\mathrm{v} / \mathrm{v})$ at $15{ }^{\circ} \mathrm{C}$ in the dark. Gram-staining of heat-fixed cells was performed as described by Murray et al. (1994). Cells of strain JHA $1^{\mathrm{T}}$ were Gram-negative, motile and slightly curved vibrios $(1.5 \mu \mathrm{m}$ wide and $2.0-3.5 \mu \mathrm{m}$ long). Formation of endospores was not observed.

Growth experiments were performed in duplicates and monitored by sulfide formation (Cord-Ruwisch, 1985) and/ or by determination of cellular protein concentration (Bradford, 1976). Growth rates were calculated from linear regression of protein production over time. The effect of $\mathrm{NaCl}$ concentration on growth was determined for the range $1-50 \mathrm{~g} \mathrm{NaCl}^{-1}$. The highest growth rates were found with $20-30 \mathrm{~g} \mathrm{NaCl}^{-1}$ and no growth was observed with $<5 \mathrm{~g}$ $\mathrm{NaCl} 1^{-1}$. Growth was tested at $\mathrm{pH}$ 5.5-8.5. The highest growth rates were found at $\mathrm{pH} 7.2-7.4$. Growth at $0-35{ }^{\circ} \mathrm{C}$ was determined in a temperature-gradient block as described elsewhere (Knoblauch \& Jørgensen, 1999). Strain $\mathrm{JHAl}^{\mathrm{T}}$ grew at $0-20{ }^{\circ} \mathrm{C}$, with the highest rates at $14-16{ }^{\circ} \mathrm{C}$, and is thus, by definition (Wiegel, 1990), a psychrophilic bacterium.
A variety of organic compounds were tested as potential electron donors for sulfate reduction. Substrates were added from sterile stock solutions at a final concentration of 2-20 mM. Hydrogen was provided $\left(\mathrm{H}_{2} / \mathrm{CO}_{2}, 90: 10\right)$ with 1 bar overpressure in the headspace. Acetate and lactate oxidation were determined with an HPLC system equipped with an Aminex HPX-87H ion-exclusion column (Bio-Rad) and analysed at $60{ }^{\circ} \mathrm{C}$ using $5 \mathrm{mM} \mathrm{H}_{2} \mathrm{SO}_{4}$ as the mobile phase. Spectrophotometric detection and quantification were performed at $210 \mathrm{~nm}$ (UVIS 204; Linear Instruments).

The psychrophilic isolate utilized a variety of organic compounds, including fatty acids, alcohols and sugars as well as amino acids (Table 1). Lactate as an electron donor was completely oxidized to $\mathrm{CO}_{2}$. Strain $\mathrm{JHAl}^{\mathrm{T}}$ shared the capacity with Desulfobacula toluolica and Desulfobacula phenolica to grow with the aromatic compound benzoate as an electron donor for sulfate reduction. In contrast to both members of the genus Desulfobacula, strain $\mathrm{JHAl}^{\mathrm{T}}$ grew chemolithoautrophically with hydrogen as a sole electron donor and with $\mathrm{CO}_{2}$ /bicarbonate as a sole carbon source. Autotrophic growth was verified by transferring the culture repeatedly into medium free of any organic substrate. Activity of $\mathrm{CO}$ dehydrogenase in a cell-free extract of strain $\mathrm{JHA}^{\mathrm{T}}$, measured as previously described at $20{ }^{\circ} \mathrm{C}$ (Galushko \& Schink, 2000), indicated the operation of the

Table 2. Major cellular fatty acids of strain $\mathrm{JHA}^{\top}$ and its closest relatives

Strains: 1, Desulfoconvexum algidum gen. nov., sp. nov. JHA1 ${ }^{\mathrm{T}} ; 2$, Desulfobacula toluolica (DSM $7467^{\mathrm{T}}$ ) (data from Kuever et al., 2001); 3, Desulfobacula phenolica (DSM 3384 ${ }^{\mathrm{T}}$ ) (Kuever et al., 2001); 4, Desulfospira joergensenii (Finster et al., 1997).

\begin{tabular}{|lcccc|}
\hline Fatty acid (\%) & $\mathbf{1}$ & $\mathbf{2}$ & $\mathbf{3}$ & $\mathbf{4}$ \\
\hline $\mathrm{C}_{14: 1}$ & - & - & 1.4 & - \\
$\mathrm{C}_{14: 0}$ & 12.7 & 8.3 & 8.7 & 13.9 \\
anteiso- $\mathrm{C}_{15: 0}$ & 0.4 & - & - & - \\
iso- $_{15: 0}$ & - & - & - & 1.8 \\
$\mathrm{C}_{15: 1} \omega 9 c$ & - & - & - & - \\
$\mathrm{C}_{15: 0}$ & 0.5 & 1.6 & 2.0 & 1.3 \\
$3-\mathrm{OH} \mathrm{C}_{14: 0}$ & 3.3 & - & 1.3 & 1.6 \\
$\mathrm{C}_{16: 1} \omega 7 c$ & 4.6 & - & - & - \\
$\mathrm{C}_{16: 1} \omega 9 c$ & 40.3 & 19.7 & 16.5 & 38.9 \\
$\mathrm{C}_{16: 1} \omega 11 c$ & 1.8 & - & - & - \\
$\mathrm{C}_{16: 0}$ & 27.8 & 31.2 & 20.4 & 28.4 \\
$\mathrm{C}_{16: 0} 10-\mathrm{methyl}$ & - & 17.6 & 17.2 & - \\
$\mathrm{C}_{17: 1} \omega 11 c$ & - & - & - & - \\
$\mathrm{C}_{17: 0}$ cyclo & 0.8 & 2.6 & 3.9 & 2.4 \\
$\mathrm{C}_{17: 0}$ & - & 0.7 & 0.7 & 0.6 \\
$\mathrm{C}_{16: 0} 3-\mathrm{OH}$ & - & - & - & 2.3 \\
$\mathrm{C}_{18: 1} \omega 13 c$ & 1.3 & - & - & - \\
$\mathrm{C}_{18: 1} \omega 11 c$ & 1.7 & 6.0 & 3.9 & 5.3 \\
$\mathrm{C}_{18: 0}$ & 1.0 & 3.1 & 2.1 & 0.7 \\
iso- $_{19: 0}$ & 1.7 & 2.5 & - & - \\
& & & & \\
\hline
\end{tabular}


reductive acetyl-CoA pathway (Wood-Ljungdahl pathway) for inorganic carbon assimilation. No activity of 2oxoglutarate dehydrogenase was found. Sulfidogenic growth with hydrogen was also observed when sulfur or thiosulfate were provided as an alternative electron acceptor in sulfatefree medium. Strain JHA1 ${ }^{\mathrm{T}}$ grew by fermentation of malate and fumarate.

Cellular fatty acid analysis was performed as described previously (Könneke \& Widdel, 2003). Cells were cultured with hydrogen and sulfate and harvested in the late exponential growth phase by centrifugation. The major fatty acids of strain JHA ${ }^{\mathrm{T}}$ were $\mathrm{C}_{14: 0}, \mathrm{C}_{16: 1} \omega 9 \mathrm{c}$ and $\mathrm{C}_{16.0}$, which were most like those of Desulfospira joergensenii (Table 2). In contrast to the two members of the genus Desulfobacula, strain $\mathrm{JHAl}^{\mathrm{T}}$ did not synthesize the methylbranched fatty acid $\mathrm{C}_{16: 0}$ 10-methyl.

The $\mathrm{G}+\mathrm{C}$ content of strain $\mathrm{JHAl}^{\mathrm{T}}$ was determined by HPLC at the Identification Service of the DSMZ (Braunschweig, Germany). The $\mathrm{G}+\mathrm{C}$ content was $46 \mathrm{~mol} \%$, which is within the range of those for the genus Desulfobacula (41-42 mol\%) and Desulfospira joergensenii (49 mol\%).
Phylogenetic analysis of the 16S rRNA gene and the alpha and beta subunits of dissimilatory adenosine-5'-phosphosulfate reductase (AprBA) was performed as described previously (Meyer \& Kuever, 2007). A large fragment of the alpha and beta subunits of the dissimilatory sulfite reductase (DsrAB) was amplified and sequenced as described previously (Loy et al., 2004). Based on the 16S rRNA gene sequence analysis, strain $\mathrm{JHAl}^{\mathrm{T}}$ affiliated with the deltaproteobacterial family Desulfobacteraceae (Fig. 1). It was almost identical ( $99 \%$ sequence similarity) to an environmental sequence obtained from coastal Antarctic sediment (Purdy et al., 2003). The closest relatives with validly described names were Desulfobacula toluolica DSM $7467^{\mathrm{T}}(94.8 \%$ sequence similarity) and Desulfobacula phenolica DSM $3384^{\mathrm{T}}$ (94.6\% sequence similarity). For the phylogenetic analysis of $d s r A B$ and $a p r B A$, only amino acid sequences generated from nearly complete gene sequences were used. A major problem is here that the database for both genes is not identical. Nevertheless, solid trees using most members of the family Desulfobacteraceae were constructed using the maximum-likelihood method with the WAG model in MEGA 5 (Tamura et al. 2011). Figs. S1 and

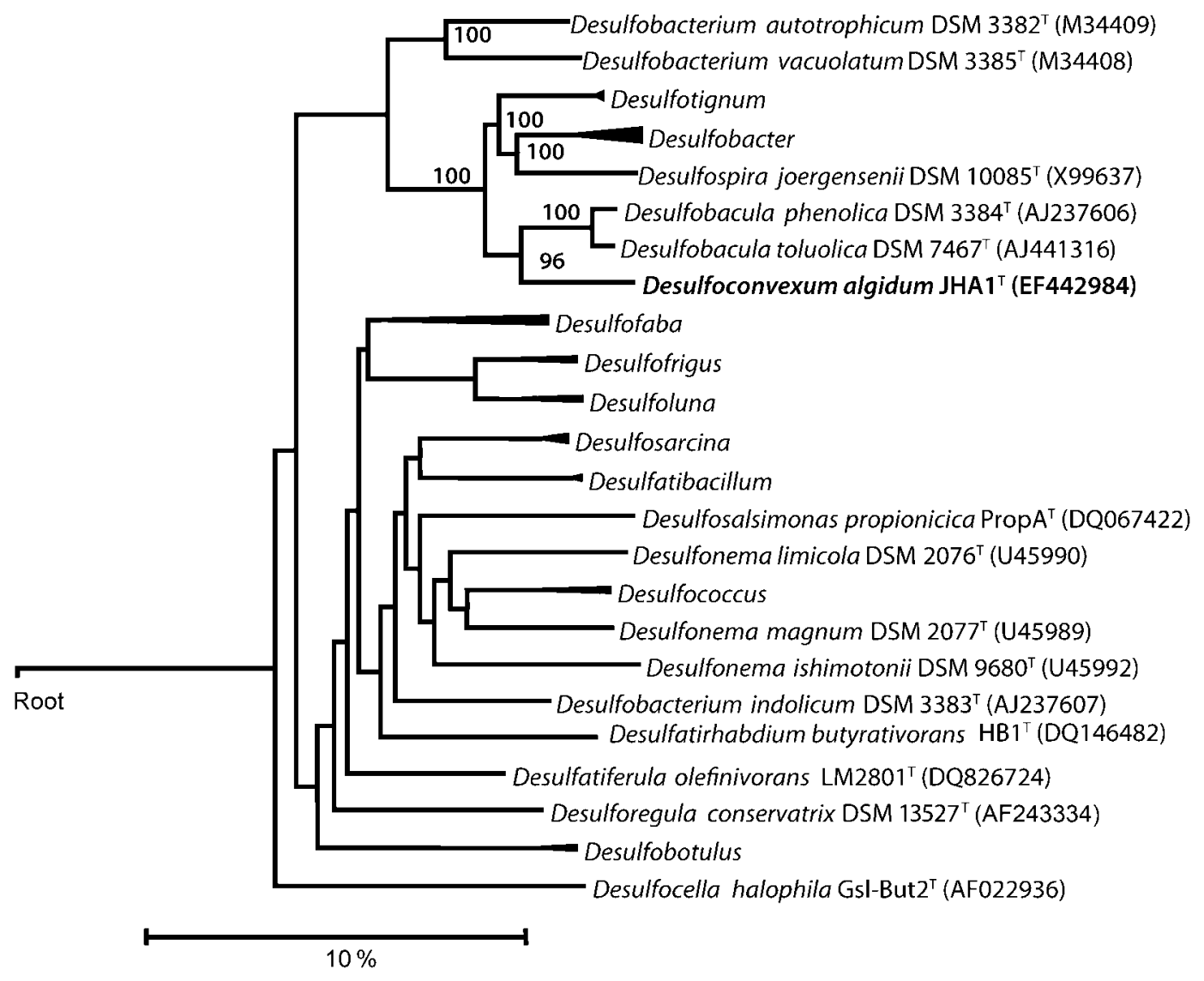

Fig. 1. Consensus neighbour-joining tree based on $16 \mathrm{~S} r R N A$ gene sequences showing the affiliation of strain $\mathrm{JHA} 1^{\top}$ to members of the family Desulfobacteraceae with validly published names. Bootstrap values ( $>70 \%)$ based on 1000 replicates are shown at branch nodes. Desulfobulbus propionicus (DSM 2052 ${ }^{\top}$; M34410) was used as an outgroup (not shown). Bar, $10 \%$ sequence divergence. 
S2 (available in IJSEM Online) show the phylogenetic trees for DsrAB and AprBA, respectively.

Both members of the genus Desulfobacula use various aromatic compounds and short-chain fatty acids as electron donors but not hydrogen. By using a common genus boundary of $<95 \% 16 \mathrm{~S}$ rRNA gene sequence similarity (Konstantinidis \& Tiedje, 2007), the 16S rRNA gene analysis of strain $\mathrm{JHAl}^{\mathrm{T}}$ suggested the establishment of a novel genus. $d s r A B$ and aprBA sequence analysis as additional phylogenetic markers supported the separation of strain $\mathrm{JHAl}^{\mathrm{T}}$ from all other genera within the family Desulfobacteraceae (Figs. S1 and S2). Whereas the DsrAB analysis showed 92-93\% similarity between the isolate and the genera Desulfospira, Desulfobacula and Desulfotignum, the AprBA analysis showed that the isolate had a close affiliation with the genus Desulfobacterium (91\% sequence similarity).

Considering the morphological, physiological and chemotaxonomic differences as well as the phylogenetic distance between strain $\mathrm{JHAl}^{\mathrm{T}}$ and members of genera of the family Desulfobacteraceae, we propose the establishment of a novel genus, Desulfoconvexum gen. nov., with Desulfoconvexum algidum sp. nov. as the type species. Members of this novel genus have been detected in the Arctic as well in the Antarctic area demonstrating their widespread distribution in permanently cold marine sediments.

\section{Description of Desulfoconvexum gen. nov.}

Desulfoconvexum (De.sul.fo.con.vex'um L. pref. de from; L. n. sulfur sulfur; L. n. n. convexum bow, curve; Desulfoconvexum sulfate reducer shaped like a curve).

Psychrophilic, marine sulfate-reducing bacteria belonging to the family Desulfobacteraceae within the delta subclass of the Proteobacteria. Cells are Gram-negative and nonspore-forming. Chemo-organoheterotrophic and chemolithoautotrophic using the $\mathrm{CO}$ dehydrogenase-dependent oxidative pathway and the reductive acetyl-CoA pathway, respectively. The type species is Desulfoconvexum algidum.

\section{Description of Desulfoconvexum algidum sp. nov.}

Desulfoconvexum algidum (al.gi'dum. L adj. n. algidum icecold, algid, living in ice-cold conditions).

Cells are curved rods or vibrioids $(1.5 \mu \mathrm{m}$ wide and 2.0 $3.5 \mu \mathrm{m}$ long). A strictly anaerobic, marine bacterium utilizing a variety of organic compounds, including fatty acids, alcohols, sugars and aromatic compounds as well as amino acids that are oxidized completely to $\mathrm{CO}_{2}$. Sulfate, thiosulfate and sulfur are used as terminal electron acceptors and are reduced to sulfide. Maximal growth rate with $20-30 \mathrm{~g} \mathrm{NaCl}$ $1^{-1}$, at $\mathrm{pH} 7.2-7.4$ and at $14-16^{\circ} \mathrm{C}$. Chemolithoautotrophic growth occurs with hydrogen and $\mathrm{CO}_{2}$ /bicarbonate. Grows by malate and fumarate fermentation. The major cellular fatty acids are $\mathrm{C}_{14: 0}, \mathrm{C}_{16: 1} \omega 9 c$ and $\mathrm{C}_{16.0}$.

The type strain is $\mathrm{JHAl}^{\mathrm{T}}\left(=\mathrm{DSM} 21856^{\mathrm{T}}=\mathrm{JCM} 16085^{\mathrm{T}}\right)$, isolated from a permanently cold marine sediment of an
Artic fjord on the north-west coast of Svalbard. The DNA $\mathrm{G}+\mathrm{C}$ content of the type strain is $46 \mathrm{~mol} \%$ (HPLC).

\section{Acknowledgements}

The authors are grateful to Michael Pilzen, Christina Probian and Ramona Appel for assistance in analytical procedures. The work was supported by the Max-Planck Society.

\section{References}

Bak, F. \& Widdel, F. (1986). Anaerobic degradation of phenol and phenol derivatives by Desulfobacterium phenolicum sp. nov. Arch Microbiol 146, 177-180.

Bradford, M. M. (1976). A rapid and sensitive method for the quantitation of microgram quantities of protein utilizing the principle of protein-dye binding. Anal Biochem 72, 248-254.

Cord-Ruwisch, R. (1985). A quick method for the determination of dissolved and precipitated sulfides in cultures of sulphate-reducing bacteria. J Microbiol Methods 4, 33-36.

Finke, N. \& Jørgensen, B. B. (2008). Response of fermentation and sulfate reduction to experimental temperature changes in temperate and Arctic marine sediments. ISME J 2, 815-829.

Finster, K., Liesack, W. \& Tindall, B. J. (1997). Desulfospira joergensenii, gen. nov, sp. nov., a new sulfate-reducing bacterium isolated from marine surface sediment. Syst Appl Microbiol 20, 201-208.

Galushko, A. S. \& Schink, B. (2000). Oxidation of acetate through reactions of the citric acid cycle by Geobacter sulfurreducens in pure culture and in syntrophic coculture. Arch Microbiol 174, 314-321.

Jørgensen, B. B. (1982). Mineralization of organic matter in the sea bed - the role of sulphate reduction. Nature 296, 643-645.

Knoblauch, C. \& Jørgensen, B. B. (1999). Effect of temperature on sulphate reduction, growth rate and growth yield in five psychrophilic sulphate-reducing bacteria from Arctic sediments. Environ Microbiol 1, 457-467.

Knoblauch, C., Sahm, K. \& Jørgensen, B. B. (1999). Psychrophilic sulfate-reducing bacteria isolated from permanently cold arctic marine sediments: description of Desulfofrigus oceanense gen. nov., sp. nov., Desulfofrigus fragile sp. nov., Desulfofaba gelida gen. nov., sp. nov., Desulfotalea psychrophila gen. nov., sp. nov. and Desulfotalea arctica sp. nov. Int J Syst Bacteriol 49, 1631-1643.

Könneke, M. (2001). Untersuchung der zellularen Fettsäuren von sulfatreduzierenden Bakterien aus kalten, marinen Sedimenten. Dissertation, Universität Bremen, Bremen, Germany.

Könneke, M. \& Widdel, F. (2003). Effect of growth temperature on cellular fatty acids in sulphate-reducing bacteria. Environ Microbiol 5, 1064-1070.

Konstantinidis, K. T. \& Tiedje, J. M. (2007). Prokaryotic taxonomy and phylogeny in the genomic era: advancements and challenges ahead. Curr Opin Microbiol 10, 504-509.

Kuever, J., Könneke, M., Galushko, A. \& Drzyzga, O. (2001). Reclassification of Desulfobacterium phenolicum as Desulfobacula phenolica comb. nov. and description of strain SaxT as Desulfotignum balticum gen. nov., sp. nov. Int J Syst Evol Microbiol 51, 171-177.

Loy, A., Küsel, K., Lehner, A., Drake, H. L. \& Wagner, M. (2004). Microarray and functional gene analyses of sulfate-reducing prokaryotes in low-sulfate, acidic fens reveal cooccurrence of recognized genera and novel lineages. Appl Environ Microbiol 70, 6998-7009.

Meyer, B. \& Kuever, J. (2007). Phylogeny of the alpha and beta subunits of the dissimilatory adenosine- $5^{\prime}$-phosphosulfate (APS) 
reductase from sulfate-reducing prokaryotes-origin and evolution of the dissimilatory sulfate-reduction pathway. Microbiology 153, 2026-2044.

Murray, R. G. E., Doetsch, R. N. \& Robinow, F. (1994). Determinative and cytological light microscopy. In Methods for General and Molecular Bacteriology, pp. 21-41. Edited by P. Gerhardt, R. G. E. Murray, W. A. Wood \& N. R. Krieg. Washington, DC: American Society for Microbiology.

Purdy, K. J., Nedwell, D. B. \& Embley, T. M. (2003). Analysis of the sulfate-reducing bacterial and methanogenic archaeal populations in contrasting Antarctic sediments. Appl Environ Microbiol 69, 3181-3191.

Rabus, R., Nordhaus, R., Ludwig, W. \& Widdel, F. (1993). Complete oxidation of toluene under strictly anoxic conditions by a new sulfatereducing bacterium. Appl Environ Microbiol 59, 1444-1451.

Rabus, R., Hansen, T. \& Widdel, F. (2000). Dissimilatory sulfate- and sulfur-reducing prokaryotes. In The Prokaryotes, an Electronic Resource for Microbiological Community. Edited by M. Dworkin, S. Falkow, E. Rosenberg, K.-H. Schleifer \& E. Stackebrandt. Heidelberg: Springer Science Online.

Ravenschlag, K., Sahm, K., Pernthaler, J. \& Amann, R. (1999). High bacterial diversity in permanently cold marine sediments. Appl Environ Microbiol 65, 3982-3989.

Ravenschlag, K., Sahm, K., Knoblauch, C., Jørgensen, B. B. \& Amann, R. (2000). Community structure, cellular rRNA content, and activity of sulfate-reducing bacteria in marine arctic sediments. Appl Environ Microbiol 66, 3592-3602.

Ravenschlag, K., Sahm, K. \& Amann, R. (2001). Quantitative molecular analysis of the microbial community in marine arctic sediments (Svalbard). Appl Environ Microbiol 67, 387-395.

Sagemann, J., Jørgensen, B. B. \& Greeff, O. (1998). Temperature dependence and rates of sulfate reduction in cold sediments of Svalbard, Arctic Ocean. Geomicrobiol J 15, 85-100.

Sahm, K., Knoblauch, C. \& Amann, R. (1999). Phylogenetic affiliation and quantification of psychrophilic sulfate-reducing isolates in marine Arctic sediments. Appl Environ Microbiol 65, 39763981.

Tamura, K., Peterson, D., Peterson, N., Stecher, G., Nei, M. \& Kumar, S. (2011). MEGA5: Molecular Evolutionary Genetics Analysis using maximum likelihood, evolutionary distance, and maximum parsimony methods. Mol Biol Evol 28, 2731-2739.

Widdel, F. \& Bak, F. (1992). Gram-negative mesophilic sulfatereducing bacteria. In The Prokaryotes. A. Handbook on the Biology of Bacteria: Ecophysiology, Isolation, Identification, Application, pp. 33523378. Edited by A. Ballows, H. G. Trüper, M. Dworkin, W. Harder \& K. H. Schleifer. New York: Springer Verlag.

Wiegel, J. (1990). Temperature spans for growth: hypothesis and discussion. FEMS Microbiol Lett 75, 155-169. 